\title{
DESIGN LANGUAGE IN MOTORCYCLE DESIGN
}

\author{
Pierre Yohanes Lubis ${ }^{1}$ \\ University of Canterbury, Christchurch, New Zealand ${ }^{l}$ \\ pierre.yohanes.lubis@gmail.com
}

\begin{abstract}
Design language as a form of non-verbal communication is comprised of shapes, colour, texture, pattern, etc. These elements of design language are the penultimate way of communication for designers, especially industrial and product designers. It is the cue that guides the consumer on how to navigate and behave with a product. In relation with motorcycle design, the author investigated on the design language of various motorcycle designs, including how different types of motorcycles for different use could significantly alter the whole design language. This research was carried out with the elements of design language in mind in order to understand it a little further and how it can assist the design process.
\end{abstract}

Keywords: design language, visual communication, motorcycle design

\begin{abstract}
Abstrak
Bahasa desain sebagai bentuk komunikasi visual terdiri dari bentuk, warna, tekstur, motif, dan lain sebagainya. Unsur-unsur bahasa desain tersebut merupakan cara berkomunikasi yang terutama bagi para desainer. Unsur-unsur tersebut memandu pengguna suatu produk tentang bagaimana mengoperasikan produk tersebut, terlebih memperlakukannya seperti apa. Dalam kaitannya dengan desain produk sepeda motor, penulis menyelidiki bahasa desain yang terdapat di alam beserta fungsinya lalu mengamati bahasa desain dari berbagai tipe sepeda motor, termasuk bagaimana sebuah sepeda motor dengan fungsi tertentu akan memiliki bahasa desain yang khas pula.
\end{abstract}

Kata kunci: bahasa desain, komunikasi visual, desain produk sepeda motor 


\section{INTRODUCTION}

Design language is a form of visual communication utilized by industrial product designers to explain a product to its users. According to Mick (1986), designers make use of semantics to interpret signals and symbols in order to relate them to usage, behaviour and objects in certain context. This type of non verbal communication is rooted in human innate intuition. A well designed product has to be clear semantically, meaning it has to be intuitive. For example, the round shape of a door handle indicates its operational mechanism, which is to be turned. This particular semantics criteria accords to the points of Ten Principles of Good Design coined by Dieter Rams (De Jong: 2017). One benefit of the design language as a form of visual communication is its ability to be understood by various demographics, without the barrier of language and culture.

\section{LITERATURE REVIEW}

\section{Design language in nature}

The human brain receives various stimuli through existing senses. Nature teaches and guides us on how to survive. Design language which exists in nature has the capability to reach human in the most primal level, which at times overwhelms human intelligence, trying to rationalize its emotional reactions. For instance, you would feel a sense of serenity while visiting the Thuringian Forest in Germany or how we feel a sense of awe when meeting wild animals in the desert of Africa. Human clearly did not invent forms, shapes, colours, and other elements found in nature, as this form of communication and language has been there long before the development of our first civilization. This form of non-verbal visual communication therefore is nothing new. We can observe various examples of design languages present in the natural world. Thompson (1917) did an extensive observation on forms found in nature. The visual pretext of a poisonous arrow frog, very contrast and inconspicuous in terms of colours, warn predators of the certainty of death. The elements of colour and motif holds a premise of death and the ability to fulfil it for other animals dare to come closer. This is how nature teaches us about consequences. Meanwhile in other parts of the globe, the physical beauty of a male peacock is a trait to win the heart of the female peacock. Physical marvels 
here communicate the promise of superior genes which in turn ensures the survival and sustainability of the species. Design aspects present in the natural world therefore explains the correlation of shape, form, and colour and so on to survival abilities, which predates the development of human language. In our society, which is predominantly verbal, meanings of the non-verbal can be rather confusing.

\section{Surface continuity in nature versus in man-made products}

When we look closer, there is a form theory which can be used to understand the shapes found in nature. This theory classifies the three types of surface continuity, each with its own meaning and message. Surface continuity stages are as based on different treatments of meeting point of two facades with different angles (Holland: 2009). Three stages of surface continuity and their corresponding meanings are:

(a) Positional, a shape which signify high level of accuracy and precision. This shape usually relates to structure and safety.

(b) Tangential, bridging the stage of positional and curvature. Hence, possess the attributes of both positional and curvature, but not in its entirety

(c) Curvature, signify elegance, fluidity and emotion.

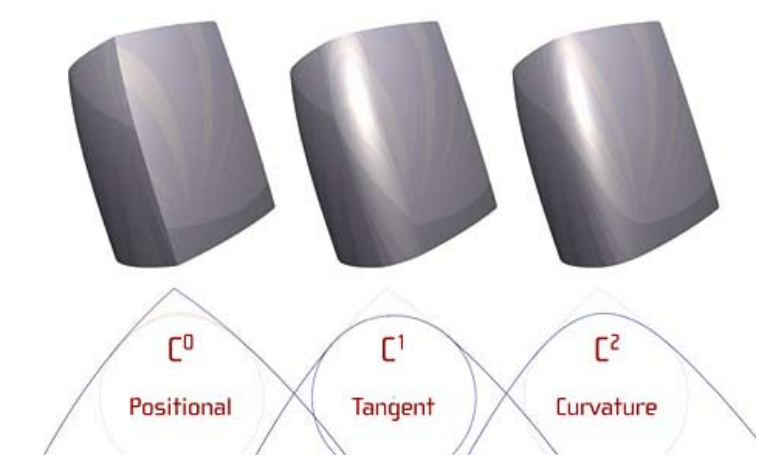

Picture 1 . The three stages of surface continuity

Source: core77.com

We can further observe the many forms found in nature. To name a few, the sharp edges of crystal formation in caves, the jagged form palm tree leaves, the 
rough scales of a desert lizard, aqua-dynamic form of dolphins, the flowing form of sedimentary stones, to the graceful curves of a flower bud.
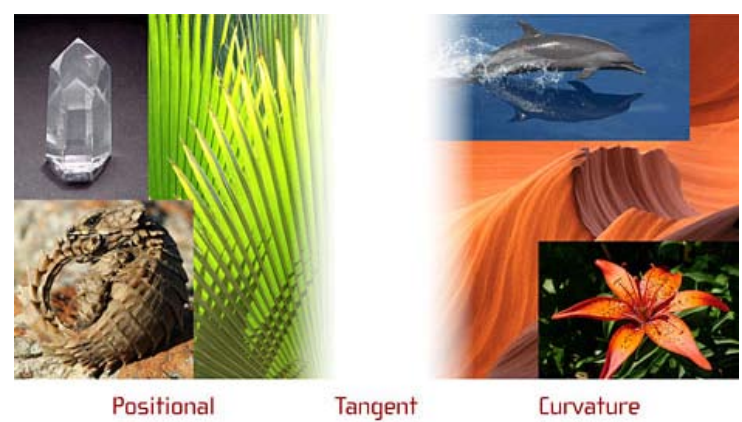

Picture 2. Three stages of surface continuity found in nature

Source: core77.com

Tangential surface continuity is almost non-existent in nature, which predominantly has either the positional or curvature surface continuity.

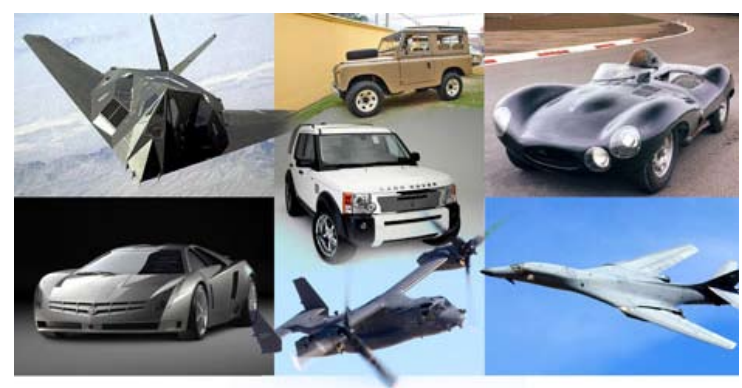

Picture 3. The three stages of surface continuity found in man-made products (left: positional, middle: tangent, right: curvature)

Source: core77.com

\section{RESEARCH METHODOLOGY}

Design as a combination of art, human factor, ergonomics and product or object, essentially strives to offer a good product experience. 


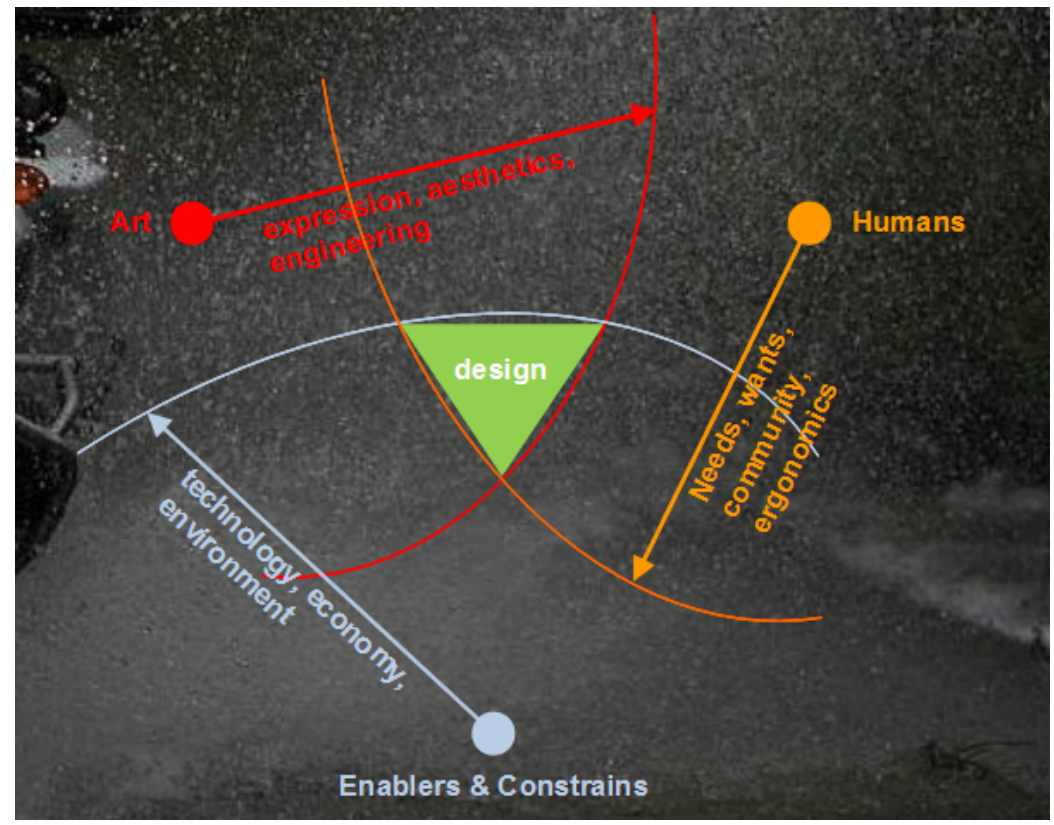

Picture 4. Design in the grand scheme of art, human, and product as

\section{enabler/constraint}

Source: slideshare.net

Therefore, a motorcycle as a product, functions as a mediator between human and experience.

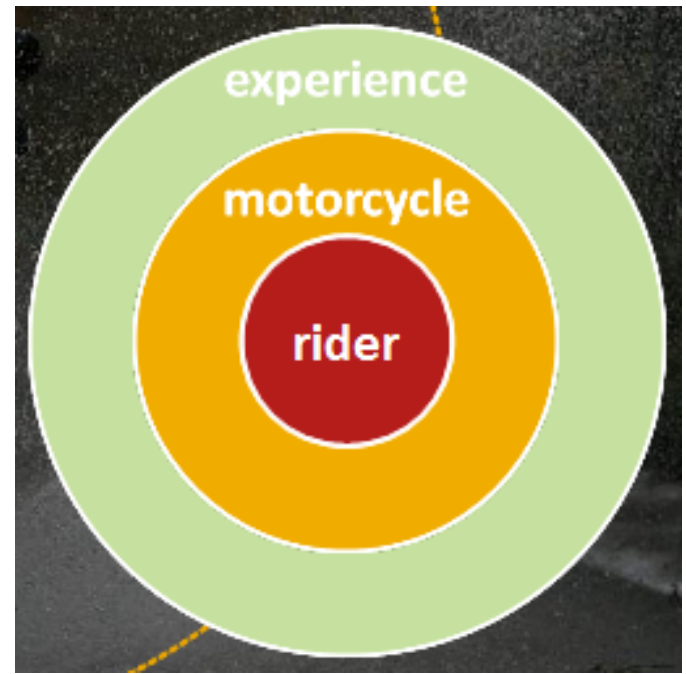

Picture 5. Motorcycle as a product serves as the mediator between human and human experience

Source: slideshare.net 
Motorcycle design is chosen as an object of the research due to the high level of communication and interaction between human and the product. This is based on the interaction between human, who provide control, with motorcycle providing feedback. This interactive communication has to be on an optimal level in order for the human to obtain a full and enjoyable experience. According to Sharma and Shmueli (2007), this form of communication (rider's control motorcycle feedback) even happens on an emotional level. Their connectivity can be explained with the picture below:

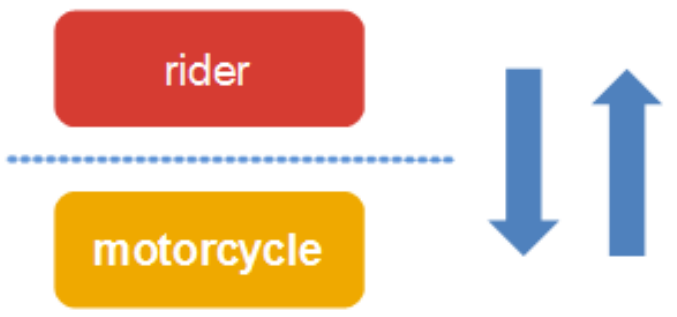

\section{Picture 6. A good communication between the rider and the motorcycle ensure an optimal experience}

Source: slideshare.net

Based on this, motorcycle as a product is regarded to be the most suitable object of this research.

This research was conducted by firstly observes the existing examples of design languages present in the natural world, including in terms of forms, shapes, colours, textures, and so on. Then, observation was made particularly in motorcycle designs as the focus. 


\section{RESULTS}

\section{Types of motorcycles according to the position of the rider}

Although various types of motorcycles exist in the market today, this research adheres to the classifications of motorcycles into three main types, which is based on the position of the handle bar, footrest and seat. From these points, a triangle can be generated, which can define what type of a motorcycle it indeed is.

\section{Cruiser}

Cruiser motorcycles offer the most comfortable position for the rider, leaning towards the back. The position of the footrest is more forward than the rider's knee. When riding, the rider's elbow tends to be lower than the handle bar of the motorcycle.

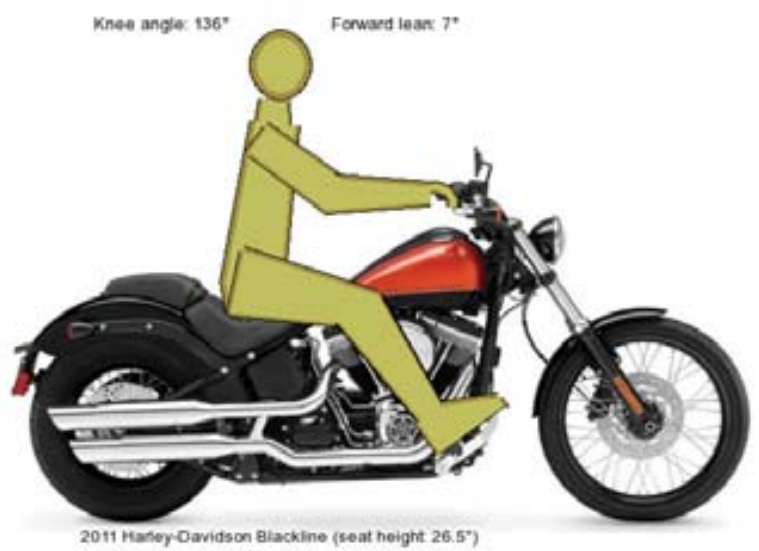

Picture 7. Rider's position when riding a cruiser motorcycle

Source: Private collection

From the position of those three points, a triangle could be made as follows:

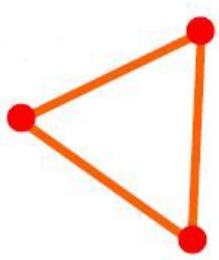

Picture 8. Triangle formed from three points: handle bar, seat and footrest on cruiser motorcycles

Source: Private collection 
Design is revolving on rider's comfort, power, and long lasting durability. Its characteristics are:

-Terrain: cross country and suburban

-Engine capacity: $250 \mathrm{cc}$ and above, durability oriented

-Usage and operational time: weekends

-Baggage need: high

\section{Dirt/Offroad}

A dirt/offroad motorcycle has the rider in an upright stance. Footrest position is rather parallel with the rider's knee. When riding, rider's elbows are slightly elevated compared to the motorcycle's handle bar.

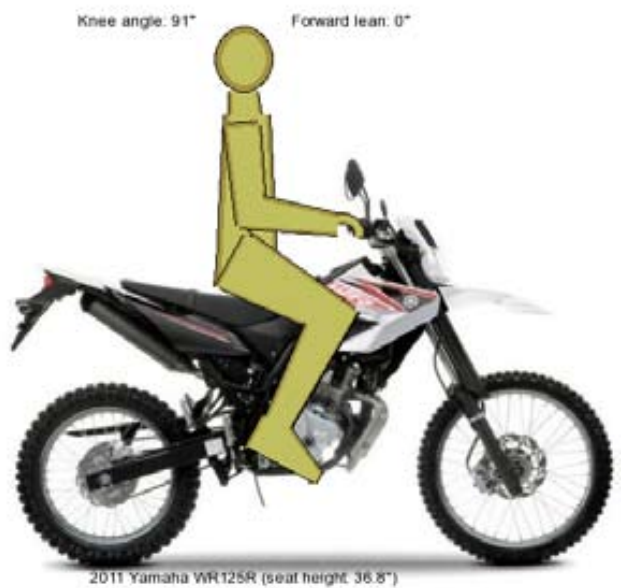

Picture 9. Rider's position when riding a dirt/offroad motorcycle

Source: Private collection

From the position of those three points, a triangle could be made as follows:

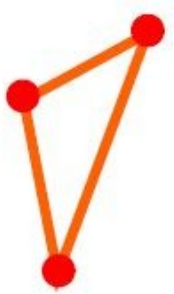

Picture 10. Triangle formed from three points: handle bar, seat and footrest on dirt/off-road motorcycles

Source: Private collection 
The design is oriented towards agility control and lower overall weight. Its characteristics include:

-Terrain: all-terrain

-Engine capacity: under $500 \mathrm{cc}$, torque oriented

-Usage and operational time: weekends

-Baggage need: Low

\section{Sport}

Sport motorcycle type is characterized by the position of the rider leaning forward. Footrest is positioned way far back from the rider's knee. When riding, the rider's elbows are higher than the handle bar.

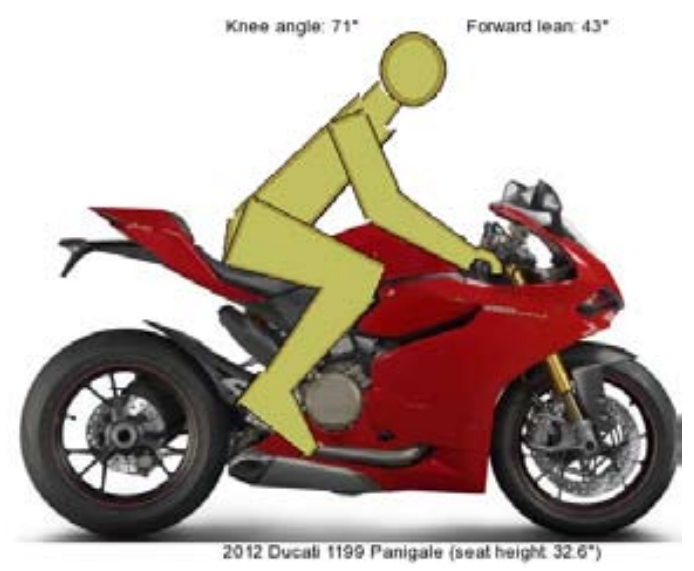

Picture 11. Rider's position when riding a sport motorcycle Source: Private collection

From the position of those three points, a triangle could be made as follows:

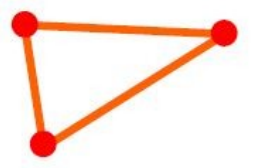

Picture 12. Triangle formed from three points: handle bar, seat and footrest on sport motorcycles

Source: Private collection 
This type is mainly focused on speed and durability. Its criteria are:

-Terrain: urban, rather flat terrain

-Engine capacity: $250 \mathrm{cc}$ and above, emphasize on speed and acceleration.

-Usage and operational time: weekdays

-Baggage need: medium

\section{Motorcycle design language according to its type}

Motorcycles are classified into three types, based on their functionality and the position of the rider. Each type conveys a distinctive meaning. When we observe them in terms of form, color and motifs, conclusions can be drawn:

(a) Cruiser

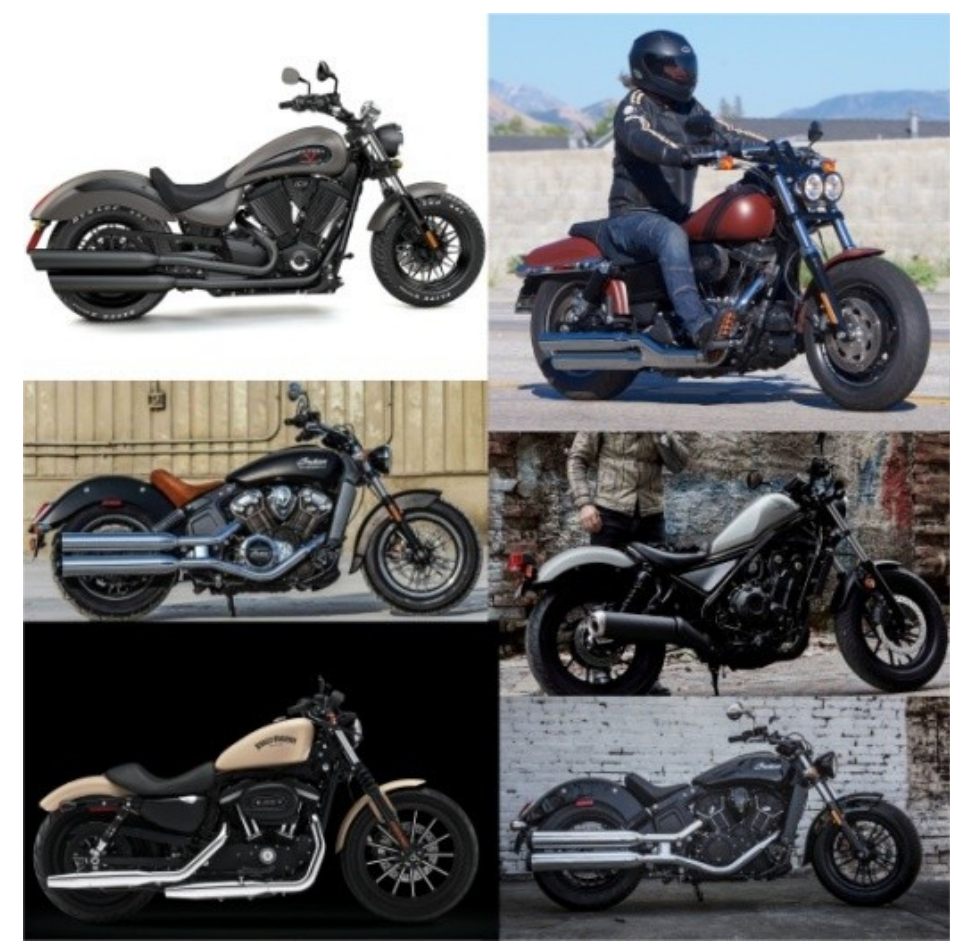

Picture 13. Cruiser motorcycles

Source: google.com

-Form and surface continuity: tends to have arch-y without pointy corner, curvature surface continuity 
-Colour palette: pastel and dark colours, gives the impression of comfort

-Motif/Striping sticker: very minimal, tends to be not present at all

In accordance to its design elements, this type of motorcycle conveys comfort and durability.

(b) Dirt/Off-road

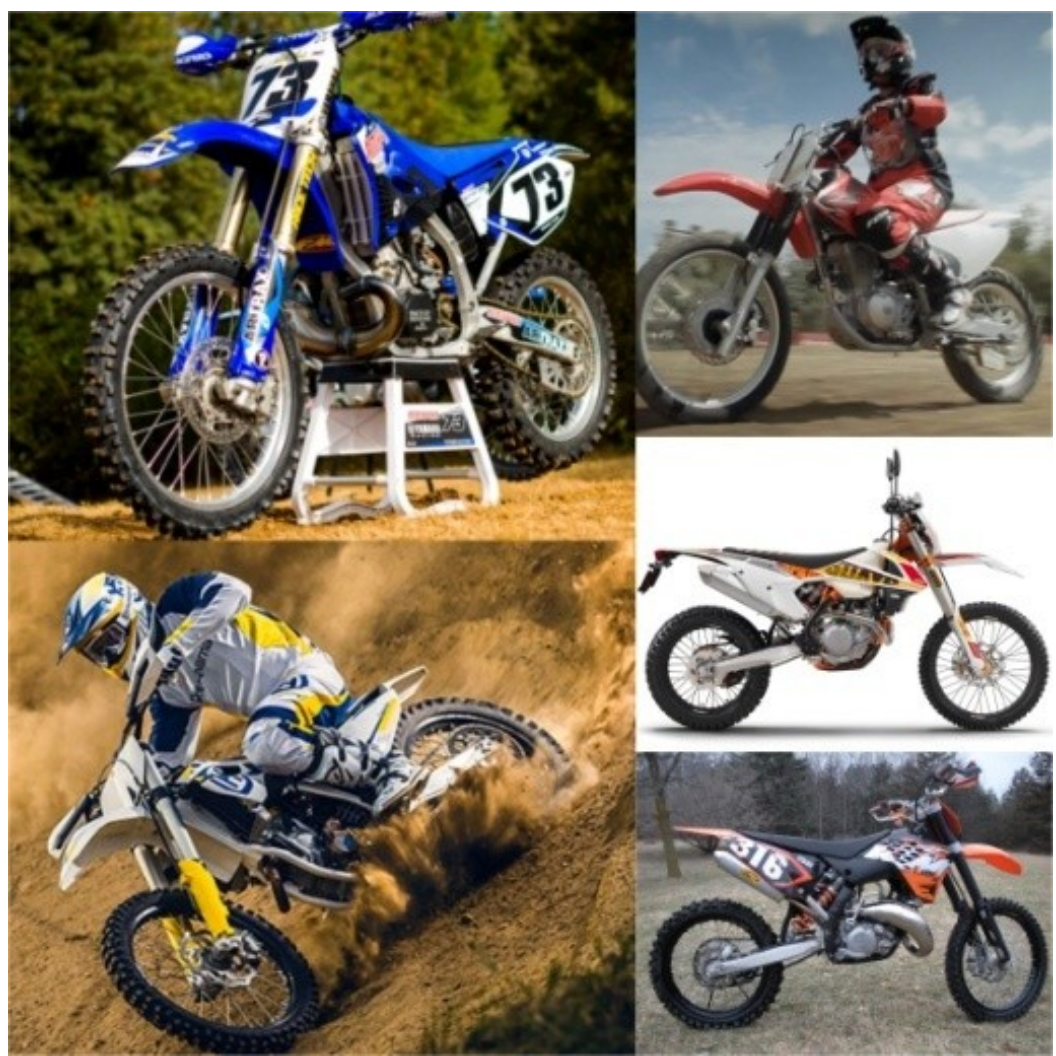

Picture 14. Dirt/off-road motorcycles

Source: google.com

-Form and surface continuity: tends to be stiff with pointy corners, positional surface continuity

-Colour palette: Bright and vibrant colours which signifies enthusiasm and energy.

-Motif/Striping sticker: dominant use of striping as the ever present element

Conforming to its design elements, this type communicates agility and the abundance of energy. 
(c) Sport

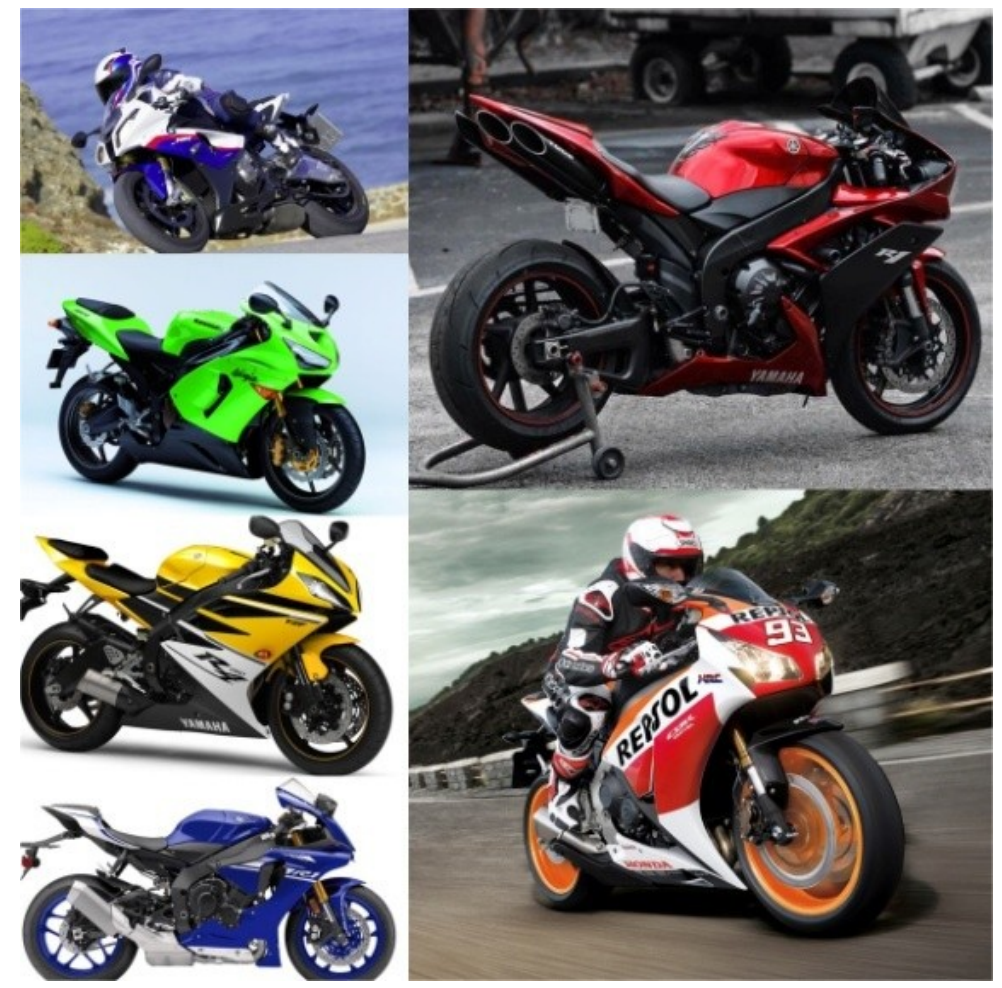

Picture 15. Sporty motorcycles

Source: google.com

- Form and surface continuity: the tendency for arches with pointy corners, tangential surface continuity

-Colour palette: bright and vibrant colours which give the impression of speed and energy

-Motif/Stripping sticker: medium

Conforming with its design elements, sport motorcycles communicates high speed

\section{CONCLUSION AND FUTURE RESEARCH RECOMMENDATION}

Every type of motorcycles has its own distinctive design language. Design language in motorcycle design, as a form of visual communication, maintains an important role in conveying meaning and impression. It is highly recommended to conduct further research on other elements of design language in other parts of 
motorcycle designs beyond the scope of this research. Moreover, future research which encompasses a more complex and deep analysis on the elements of design language. Other recommendations include conducting a comprehensive research on elements of design language in other man-made products.

\section{REFERENCES}

Aspettati, P., Barone, S., Curcio, A., $\quad$ Picone, M. 5-7 Sep 2001. "Parametric and feature-based assembly in motorcycle design: from preliminary development to detail definition". XII ADM International Conference.

De Jong, C. W. 2017. Dieter Rams: Ten Principles for Good Design. Munich: Prestel Verlag.

Holland, G. 2 Mar 2009. A Periodic Table of Form: The Secret Language of Surface and Meaning in Product Design. Core77. Available here

Mick, D. 13 Sep 1986. "Consumer Research and Semiotics: Exploring the Morphology of Signs, Symbols and Significance". Journal of Consumer Research.

Sharma, A., Shmueli, S. 22 Oct 2007. "Motorcycle and The Art of Product Design". Connecting'07 World Design Congress. Available here

Thompson, D.W. 1917. On Growth and Form. Cambridge: Cambridge University Press. 